УДК 614.2 (07)

DOI 10.11603/me.2414-5998.2019.3.10125

\author{
О. С. Никоненко, С. Д. Шаповал, С. М. Дмитрієва, Т. О. Грицун
}

Державний заклад «Запорізька медична академія післядипломної освіти Міністерства охорони здоров'я України»

\title{
ЗАСТОСУВАННЯ КОМПЕТЕНТНІСНОГО ПІДХОДУ ПРИ ОРГАНІЗАЦІЇ ОЧНО-ЗАОЧНОГО НАВЧАННЯ НА РІЗНИХ ЕТАПАХ ПІДГОТОВКИ ЛІКАРІВ
}

\author{
O. S. Nykonenko, S. D. Shapoval, S. M. Dmytriieva, T. O. Hrytsun \\ Zaporizhzhia Medical Academy of Postgraduate Education \\ APPLICATION OF THE COMPETENT APPROACH IN THE \\ ORGANIZATION OF THE PART-TIME EDUCATION AT DIFFERENT \\ STAGES OF TRAINING OF DOCTORS
}

\begin{abstract}
Мета роботи - аналіз ефективності педагогічних умов формування фахових компетентностей лікарів при організації очнозаочного навчання у Державному закладі «Запорізька медична академія післядипломної освіти Міністерства охорони здоров’я України» (ДЗ «ЗМАПО МОЗ України»).

Основна частина. Доведено, що формування професійних компетенцій лікарів залежить від застосування різних підходів до реалізації цілей навчання, мотивації та прагнення підвищувати свій професійний рівень. Перспективним напрямком підвищення фахової освіти у ДЗ «ЗМАПО МОЗ України» визначено застосування дистанційних технологій, зокрема при проведенні різноманітних навчальних моделей із застосуванням освітнього середовища Moodle, у тому числі через фахові Internet-pecypси. Представлено досвід проведення кафедрами академії циклів очно-заочної післядипломної підготовки та безперервного професійного розвитку лікарів за дистанційними методами. Підкреслено, що навчання на основі компетентнісного підходу 3 використанням дистанційних технологій мотивує учасників. Визначено рівень сформованості фахових компетенцій лікарів.

Висновок. Організація очно-заочного навчання, що грунтується на компетентнісному підході, підвищує мотивацію до самоосвіти лікарів та сприяє застосуванню необхідних знань у сфері їх професійного й особистісного розвитку.
\end{abstract}

Ключові слова: очно-заочне навчання; професійні компетенції лікарів.

The aim of the work - to analyze the effectiveness of the pedagogical conditions to the formation of professional competencies of doctors in the organization of part-time education at the State Institution "Zaporizhzhia Medical Academy of Postgraduate Education of the Ministry of Health of Ukraine” (ZMAPO).

The main body. It is shown, that the formation of professional competences of doctors depends on the application of different approaches to the realization of educational goals, motivation and the desire to improve their professional level. As promising direction of the raising professional education in the ZMAPO we determined the use of remote technologies, in particular, the conducting various educational models and environments, including professional Internet resources. The experience of the organization of courses of the correspondence training in postgraduate education and continuous professional development of physicians by distance methods is presented. It is emphasized, that the education of doctors based on the competent approach using remote technologies motivates participants. The aimed level of formation of professional competencies of doctors is determined.

Conclusion. Organization of the part-time education, based on a competent approach, increases the motivation to self-education of doctors and promotes the application of the necessary knowledge in the field of their professional and personal development.

Key words: part-time training; professional competences of doctors.

Вступ. Реформи в галузі охорони здоров’я вносять свої корективи у сферу медичної освіти, зокрема підвищення якості навчання на різних етапах підготовки лікарів. Постановою Кабінету Міністрів України від 28 березня 2018 р. № 302 «Про затвердження Положення про систему безперервного професійного розвитку фахівців у сфері охорони здоров’я» визначено основні організаційні засади безперервного процесу навчання, вдосконалення професійних компетентностей фахівців після здобуття ними вищої освіти у сфері охорони здоров'я та післядипломної освіти в інтернатурі $[5,6]$.

Загальноприйнятими факторами формування професійних компетентностей фахівців є соціальні,

(ㄱ О. С. Никоненко, С. Д. Шаповал, С. М. Дмитрієва, Т. О. Грицун 
психологічні й організаційно-педагогічні. Враховуючи специфіку професійної діяльності лікаря, його професійна компетентність базується на ключових навичках, а саме: професійних, комунікативних, дослідницьких та наукових [1].

Ефективність підготовки лікарів вимагає різних підходів до реалізації цілей і залежить від мотивації, рівня підготовленості, прагнення навчатися, підвищувати свій професійний рівень. Навчання на основі компетентнісного підходу (вміння використати набуті знання, навички, досвід у конкретно даних умовах, досягнувши при цьому максимально позитивного результату) формує у лікарів якості для реалізації професійної діяльності, які необхідні для ринку праці [6].

Модернізація навчання зумовлює оптимізацію технологій, форм та способів викладення матеріалу. Перспективним напрямком підвищення фахової освіти лікарів є застосування технологій дистанційного навчання, у тому числі через фахові Internetресурси, зокрема при організації очно-заочної форми. Це зручний і доступний формат проведення, який доступний будь-якому лікарю, незалежно від його місця знаходження [2].

Мета роботи - аналіз ефективності педагогічних умов формування фахових компетентностей лікарів при організації очно-заочного навчання у Державному закладі «Запорізька медична академія післядипломної освіти Міністерства охорони здоров’я України» (ДЗ «ЗМАПО МОЗ України»).

Основна частина. Організація очно-заочної підготовки у ДЗ «ЗМАПО МОЗ України» грунтується на компетентнісному підході, що передбачає поглиблення професійних знань слухачів, умінь, практичних навичок у роботі відповідно до їх спеціальності та використання у своїй практичній діяльності. За дистанційними методиками кафедри академії розробили і вдало апробували нові формати - дистанційні модулі при проведенні очно-заочних циклів післядипломної підготовки та безперервного професійного розвитку лікарів (БПРЛ), зокрема цикли тематичного удосконалення, короткострокові курси інформації і стажування з майстер-класом [3].

Відповідно до Положення про підготовку та підвищення кваліфікації лікарів за очно-заочною формою з елементами дистанційного навчання у ДЗ «ЗМАПО МОЗ України», перший етап (заочний) передбачає дистанційну підготовку з використанням веб-ресурсів, взаємодію між викладачами і слухачами у синхронному та асинхронному режимах. Другий етап (очний) передбачає проходження навчання на кафедрі, співбесіду (контроль знань) й оформлення необхідних документів за результатами оцінки теоретичної та практичної підготовки [5].

Модель очно-заочного навчання передбачає опанування теоретичних знань під час проходження лікарями дистанційних курсів, оформлених в освітньому середовищі Moodle, та практичної частини на кафедрах академії з демонстрацією та відпрацюванням практичних навичок на заняттях, тренінгах, майстер-класах із використанням сучасних технічних засобів.

При розробці дистанційного контенту викладачі ДЗ «ЗМАПО МОЗ України» враховують принципи індивідуальності, доступності, практичної спрямованості та результативності. Навчальний матеріал формується відповідно до критеріїв відбору змісту: відповідності навчальній програмі; можливості реалізації програми курсу (умови, матеріально-технічна база навчального закладу тощо), з урахуванням сучасних досягнень у даній галузі. При створенні дистанційних модулів використовуються фахові Internet-ресурси та сервіси Google. Дистанційний курс містить різні елементи: лекції, практичні завдання, форум, чат тощо. При цьому використовуються текст, презентації, таблиці, схеми, електронні атласи зображень, відеоматеріали, посилання в мережі Internet, зокрема на нормативну базу, електронні видання, публікації та інші фахові матеріали [4]. Серед основних переваг побудови дистанційного контенту є можливість оперативно корегувати інформаційний матеріал, робити кейси на прикладах подій, які відбуваються на даний момент. У ДЗ «ЗМАПО МОЗ України» дистанційні кейс-технології використовуються в рамках освітніх програм з актуальних проблем сучасного клінічного навчання, доказової медицини, біоетики.

Водночас для якісного забезпечення навчання за допомогою середовища Moodle можливе поєднання online та offline складових: перегляд та опанування матеріалу з обговоренням окремих питань під час Internet-дискусій із використанням форуму або чату, участю у науково-практичних Web-семінарах та конференціях; організація телеконсультацій тощо.

Науково-методичне забезпечення очно-заочних циклів ДЗ «ЗМАПО МОЗ України» включає насамперед практичні рекомендації щодо розроблення i використання педагогічно-психологічних та інфор- 
маційно-комунікаційних технологій; критерії, засоби і системи контролю якості освіти [5].

Центральна методична рада академії ухвалила пакет науково-методичного забезпечення циклів очно-заочного навчання, який містить: робочу програму циклу; методичні вказівки для самостійної роботи слухачів або короткі інструкції з виконання завдань, розміщених в Moodle; інформаційний матеріал (контент) курсу; перелік інформаційних ресурсів та Internet-посилань; глосарій термінів (за необхідністю). Переглянуті вимоги щодо оформлення основної документації - запропонована структура анотації online курсу та робочої програми; в пояснювальній записці обов'язково вказується співвідношення очної та заочної частин 3 описом особливостей організації на платформі Moodle (в якій формі представлені заняття, як проводиться контроль і самоконтроль знань, критерії оцінювання).

Рівень сформованості фахових компетенцій лікарів оцінюється на різних етапах проходження очно-заочного навчання, використовуючи різні методи та інструменти зворотного зв'язку: анкетування, тестування, оцінювання активності участі на заняттях, самооцінювання, вирішення клінічних

\section{Список літератури}

1. Вороненко Ю. В. Післядипломна медична освіта - нові горизонти й перспективи / Ю. В. Вороненко, О. П. Мінцер, О. В. Палагін // Медична освіта. - 2016. № 3. - С. 12-16. - Режим доступу : http://nbuv.gov.ua/ UJRN/Mosv_2016_3_5.

2. Долженко М. Н. Дистанционное обучение в системе медицинского последипломного образования в Украине / М. Н. Долженко, Роберт Бендер // Зб. наук. праць співробітників КМАПО ім. П. Л. Шупика. - К., 2014. C. 546-550.

3. Організаційне забезпечення післядипломної освіти медичних спеціалістів у ДЗ «ЗМАПО МОЗ України» / О. С. Никоненко, С. Д. Шаповал, С. М. Дмитрієва,

\section{References}

1. Voronenko, Yu.V., Mintser, O.P., \& Palahin, O.V. (2016). Pisliadyplomna medychna osvita - novi horyzonty i perspektyvy [Postgraduate medical education - new horizons and perspectives]. Medychna osvita - Medical Education, 3, 12-16. Retrieved from: http://nbuv.gov.ua/ UJRN/Mosv_2016_3_5 [in Ukrainian].

2. Dolzhenko, M.N., \& Bender, Robert (2014). Dystantsyonnoe obuchenye $\mathrm{v}$ systeme medytsynskogo завдань різних типів і рівнів тощо. Установлення узагальненого рівня сформованості фахових компетенцій визначається шляхом сумарної оцінки наприкінці курсу.

Як свідчать результати анкетування та опитування викладачів академії, при організації форматів очно-заочного навчання актуальними залишаються питання педагогічного навантаження викладачів, відсутності технічної підтримки, кваліфікованих фахівців (модераторів), доцільності проведення очно-заочних циклів в асинхронному режимі. Не вирішені питання 3 авторськими правами викладачів, ідентифікації особистості, не до кінця розроблені стандарти якості та методики здійснення дистанційної освіти [4].

Висновок. Організація очно-заочного навчання, що грунтується на компетентнісному підході, підвищує мотивацію до самоосвіти лікарів; актуалізує потребу в розробленні якісної відкритої системи післядипломної освіти та БПРЛ; за допомогою Internet-ресурсів забезпечує вільний доступ до інформації, тим самим сприяє застосуванню необхідних знань у сфері їх професійного й особистісного розвитку.

Т. О. Грицун // Медична освіта. - 2017. - № 3. - С. 62-64. 4. Організація дистанційного навчання. Створення електронних навчальних курсів та електронних тестів : навч. посіб. / В. В. Вишнівський, М. П. Гніденко, Г. І. Гайдур, О. О. Ільїн. - К. : ДУТ, 2014. - 140 с.

5. Про затвердження Положення про дистанційне навчання : наказ Міністерства освіти і науки України від 25.04.2013 р. № 466. - Режим доступу : https://zakon. rada.gov.ua/laws/show/z0703-13.

6. Про затвердження Положення про систему безперервного професійного розвитку фахівців у сфері охорони здоров’я : Постанова Кабінету Міністрів України від 28 березня 2018 р. № 302. - Режим доступу : https:// zakon.rada.gov.ua/laws/show/302-2018-\%D0\%BF.

posledyplomnogo obrazovaniya v Ukraine [Distance education in the system of medical postgraduate education in Ukraine]. Zbirnyk naukovykh prats spivrobitnykiv KMAPO im. P.L. Shupyka - Collection of Scientific Papers of the Employees of the KMAPO by P.L. Shupyk. Kyiv [in Russian]. 3. Nykonenko, O.S., Shapoval, S.D., Dmytrieva, S.M., \& Hrytsun, T.O. (2017). Orhanizatsiine zabezpechennia pisliadyplomnoi osvity medychnykh spetsialistiv u 
DZ “ZMAPO MOZ Ukrainy” [Organizational support of postgraduate education of medical specialists in DZ “ZMAPO of the Ministry of Health of Ukraine”]. Medychna osvita - Medical Education, 3, 62-64 [in Ukrainian].

4. Vyshnivskyi, V.V., Hnidenko, M.P., Haidur, H.I., \& Iliin, O.O. (2014). Orhanizatsiia dystantsiinoho navchannia. Stvorennia elektronnykh navchalnykh kursiv ta elektronnykh testiv [Organization of distance learning. Creating e-learning courses and electronic tests]. Kyiv: DUT [in Ukrainian].

5. Nakaz Ministerstva osvity i nauky Ukrainy № 466 vid 25.04.2013 "Pro zatverdzhennia Polozhennia pro dystantsiine navchannia" [Order of the Ministry of
Education and Science of Ukraine No. 466 dated April 25, 2013 "On Approval of the Regulations on Distance Learning”]. Retrieved from: https://zakon.rada.gov.ua/laws/ show/z0703-13 [in Ukrainian].

6. Postanova Kabinetu Ministriv Ukrainy vid 28 bereznia 2018 r. № 302 “Pro zatverdzhennia Polozhennia pro systemu bezperervnoho profesiinoho rozvytku fakhivtsiv u sferi okhorony zdorovia" [Resolution of the Cabinet of Ministers of Ukraine dated March 28, 2018, No. 302 “On Approval of the Regulation on the System of Continuous Professional Development of Specialists in the Sphere of Health Care"]. Retrieved from: https://zakon.rada.gov.ua/laws/show/3022018-\%D0\%BF [in Ukrainian].

Електронна адреса для листування: metod.zmapo@gmail.com 